\title{
Using Interactive Whiteboards as an Assistive Technology for Students with Intellectual Disability*
}

\author{
Ömer Arpacık**
}

\author{
Engin Kurş un ${ }^{* * *}$
}

\author{
Yüksel Göktaş****
}

\begin{abstract}
The aim of this study is to investigate the impact of integrating interactive whiteboard (IWB) on students' participation and teachers' teaching practices in a special education school. The case study method was employed in this study. The study was carried out in a special education school with four students two of whom are mentally disabled, one with Down's syndrome and one with autism and two special education teachers. Data was collected through about 20 hours observations in natural settings of a special education school and a number of semi-structured interviews with two teachers during 6 weeks study period. Content analysis method was administrated in data analysis. As a result of the research, various findings were obtained about the quality of the used visuals, the use of touch screen, the students gainig new behaviors, students with different characteristics showing obsessive behaviours, group work and class control. The results show that the use of interactive whiteboards is advantageous in some ways such as having a large screen, supporting multi-media and interaction. In addition, students did not have any difficulties using the IWB. Repeating a process hundreds of times and adaptability of materials for the needs of each student were the important findings which rationalize integrating IWB in special education settings. However, teachers had some trouble with class management at the beginning, but they were able to overcome these problems over time.
\end{abstract}

Keywords: intellectually disability, assistive technology, special education, interactive whiteboard

\footnotetext{
* This study is derived from the first author's PhD dissertation.

Assist. Prof. Dr., Ataturk University, Faculty of Education, Department of Computer Education and Instructional Technology, Erzurum, Turkey. E-mail: omerarpacik@gmail.com

**** Assoc. Prof. Dr., Ataturk University, Faculty of Education, Department of Computer Education and Instructional Technology, Erzurum, Turkey. E-mail: enginkursun@gmail.com

${ }_{* * * * *}$ Prof. Dr., Ataturk University, Faculty of Education, Department of Computer Education and Instructional Technology, Erzurum, Turkey. E-mail: yukselgoktas@atauni.edu.tr
} 


\title{
Etkileşimli Tahtanın Zihinsel Engelli Öğrencilerin Eğitiminde Yardımcı Teknoloji Olarak Kullanımı
}

\begin{abstract}
$\ddot{O} \mathbf{z}$
Teknoloji birçok alanda insanların hayatlarını kolaylaştırırken engelli bireylerin hayatında daha önemli bir yere sahip olmaktadır. Bu çalışmanın amacı, etkileşimli tahtanın özel eğitim uygulama okullarında kullanımının öğrencilerin katılımı ve öğretmenlerin ders işlemeleri üzerine etkisini incelemektir. Çalışmada durum çalışması yöntemi kullanılmıştır. Çalışma bir özel eğitim uygulama okulunda bulunan ikisi orta derecede zihinsel engelli, biri down sendromlu ve biri otistik olmak üzere dört öğrenci ve iki özel eğitim öğretmeni ile gerçekleştirilmiştir. Veriler, özel eğitim okulunda 6 hafta boyunca toplamda 20 saat öğrencilerin gözlemlenmesi ve iki öğretmen le yapılan yarı yapılandırılmış görüşmelerden elde edilmiştir. Veri analizinde içerik analizi yöntemi kullanılmıştır. Araştırma sonucunda kullanılan görsellerin kalitesi, dokunmatik ekran kullanımı, öğrencilerin yeni davranışlar kazanması, farklı özelliklere sahip öğrencilerin obsesif davranışlar göstermesi, grup çalışması, sınıf kontrolü ile ilgili çeşitli bulgular elde edilmiştir. Çalışmada öğrencilerin etkileşimli olarak materyali kullanabilmesi, etkileşimli tahtanın çoklu ortam nesnelerini desteklemesi ve ekranın büyük olmas1 avantaj olarak görülmüştür. Bunun yan1 sıra, öğrencilerin etkileşimli tahtayı kullanmalarında herhangi bir zorluk yaşamadıklarını tepsit edilmiştir. Ayrıca, etkileşimli tahtanın kullanılması ile öğretimin defalarca tekrarlanabilmesi ve materyallerin her öğrencinin ihtiyaçları için uyarlanabilmesi, çalışmadan elde edilen önemli bulgulardır. Bununla beraber, öğretmenlerin başlangıçta sınıf yönetimi ile ilgili bazı sorunlar yaşadığı, ancak bu sorunları zamanla aşılabileceği görülmüştür.
\end{abstract}

Anahtar Sözcükler: Zihinsel engel, yardımcı teknolojiler, özel eğitim, etkileşimli tahta 


\section{Introduction}

The impact of information and communication technologies (ICT) is affecting all areas of society, including education, healthcare, transportation, communications, security and food (Stahl, Rogerson, \& Wakunuma, 2009). It directly or indirectly improves the quality of lives of individuals in a wide variety of ways. However, the majority of these technologies are developed for individuals without disabilities and they do not provide any benefits for individuals with different disabilities (Williams \& Nicholas, 2006; Y1ldı, 2010). Also, technologies for individuals with disabilities are not being developed at the same rate as those for individuals without disabilities (Davies, Stock, \& Wehmeyer, 2004). Considering $12 \%$ of the world's population lives with some form of disability, the importance of technologies specifically developed for these people is clearly apparent (World Report on Disability, 2011).

As mention below, although the technology has very significant role in individuals with disability, developing technologies for these people is not enough. But, they can use technology in every stage in their life and that facilitate their daily routines. Technologies used to facilitate the lives of individuals with disabilities are named as assistive technologies. In other words, any object, equipment or product used to increase, maintain and improve the functional capability of individuals with disabilities are defined as assistive technologies (Braddock, Rizzolo, Thompson, \& Bell, 2004). Some of the assistive technologies that people with disabilities use in different activities in their daily lives, are: computers, tablets, mobile devices, electrical or manual wheelchairs, canes, walkers and standing tools, screen readers, hearing aids, navigation assistance, wearable technologies etc.

The significant facilitate of assistive technology is used them in educational process of individual with intellectual disabilities. People with intellectual disabilities are characterized by significantly impaired intellectual functioning and behaviors (Braddock et al., 2004). Two main problems for intellectually disabled people are the fact that they forget very quickly and learn very difficult (Rezaiyan, Mohammadi, \& Fallah, 2007). This might be caused by some difficulties encountered in information processing (Lopresti, Bodine, \& Lewis, 2008). ICT increases motivation when properly used in the educational system, provides forindividual learning and new teaching approaches, increases the productivity ofteachers and allows students to gain new skills required by technology in the information age(Roblyer \& Edwards, 2000). The use of technology is very important for education, particularly forindividuals with disabilities (Williams \& Nicholas, 2006) because technologies can provide better learning environments for such people through their inclusion in school classrooms(Yildiz, 2010). In many studies, it has been seen that the use of assistive technologies has positive impacts on the learning activities of people with intellectual disabilities (Jeffs, Behrmann, \& Bannan-Ritland, 2006; Mosito, Warnick, \& Esambe, 2017; Rose, Hasselbring, Stahl, \& Zabala, 2005; Twyman \& Tindal, 2006; Wiley, Cameron, Gulati, \& Hogg, 2016).

This study has been conducted as a response to the fact that less technology is used at schools for special education and, as can be seen in the literature as mention below, the use of technology is very important for students with intellectual disabilities. Therefore, the use of IWB in theclassroom of students with intellectual disabilities at a special education school wasinvestigated in terms of students' participation and effects of IWBon special education teachers' teaching practices. IWB increases participation and academic engagement for all students via multimedia ability, motivation, efficacy etc (Whitby, Leininger, \& Grillo, 2012). Also IWB increase the interactivity of students with disability, provides interaction, instant feedback, visuals and audios. And IWB allows using specific content for each student (Allsopp et al., 2012).

This study focuses on the impact of courses assisted by multi-media materials presented through IWBs on the education of intellectually disabled students. Our particular concerns are with their impact on students' participation and teachers' teaching practices in the classroom. 


\section{Overview}

\section{Method}

For this study, the case study method, which is one of the qualitative research design, waspreferred. The case studyis a method of research using a case in detail when there are no certain boundaries between the case and content under real-life conditions (Y in, 1984, p18). This studycan also be regarded as a case study since students and teachers are examined in their real environments, and data were collected from multiple sources such as interviews with teachers, video recordings and students' observations.

\section{Participants}

The study was conducted on 4 students, comprising 3 males and one female, and two special education teachers at a school for special education in a city in the east of Turkey. These students were selected through the purposive sampling method. One of the students has Down's Syndrome, two of them have moderate intellectual disabilities and the remaining one hasautism. The student with Down's Syndrome is 11 years old, the student with autistic disorder is nine years old and the other two students with intellectual disabilities are 12 and 13 years old. The teachers have computer skills, whereas the students do not have any computerskills.

\section{Data Collection Tools and Data Analysis}

Data were collected through observations and interviews. Observation and interview scheduleswere prepared based on research questions by researchers. Peers and expert's opinions were gathered and pilot study for these schedules were conducted. Then, necessary changes have been made in line with their feedbacks and pilot study.

Interviews were conducted with teachers before, during and after implementation of the study. One of the researchers carried out observations for 20 hours over 6 weeks while IWB being used in the classrooms. These lessons were captured by video recorder. With the data obtained, content analysis was performed by creating a framework from the aspects that fall within the research questions, observations and interviews. Then, data were brought together in a meaningful and logical manner according to the thematic framework. For the validity and reliability of the data collection and analysis, peer-reviews were carried out and all interviews and observations were recorded.

\section{Process}

Before the study, the school administration was consulted and the classroom to be studied was selected. All necessary permissions from the authorities were obtained. The classroom selected was examined and the dimensions of the classroom were checked to see whether an interactive whiteboard could be installed. The IWB was brought to the classroom four months before the start date of the study. In this way, the effect of the innovation brought by a new technology was reduced.

After installing the IWB, teachers were asked to choose a subjectwhich students did not have any idea about. They chose the subject of teaching animal names, and practice activities on this topic were carried out on the IWBover a period of 6 weeks, in an orderly manner. In thisperiod, practice took place over a total of 20 class hours, except for some holidays and days when a required number of students were not able to attend the class. These lessons were treated as teaching and observation sessions. Relevant concepts were taught and evaluations were done to see whether students had learnt the name of the animal taught in the previous session. In monitoring sessions, conducted after 1, 2 and 4 weeks following the teaching sessions, it was concludedin fact that the students did not learn.

First step of the process in teaching sessions was that the teacher showed an animal in the center of the screen and tought the name of the animal, for example dog (Figure 1). Then teacher selected the first activity, which included the dog with another animal. Then the teacher asked to student which was the dog and wanted him to show the dog (Figure 2). The second, third, fourth and fifth activities were similar to the first activity but with different 
animals and in different places. After that process if student answered correctly four of five in minimum, teacher went on teaching the next animal.

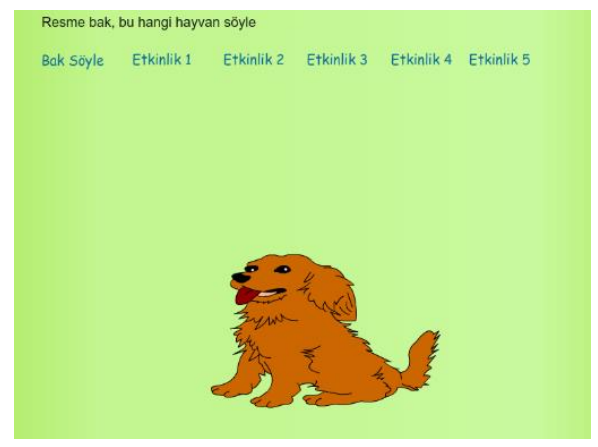

Figure 1. Look and tell.

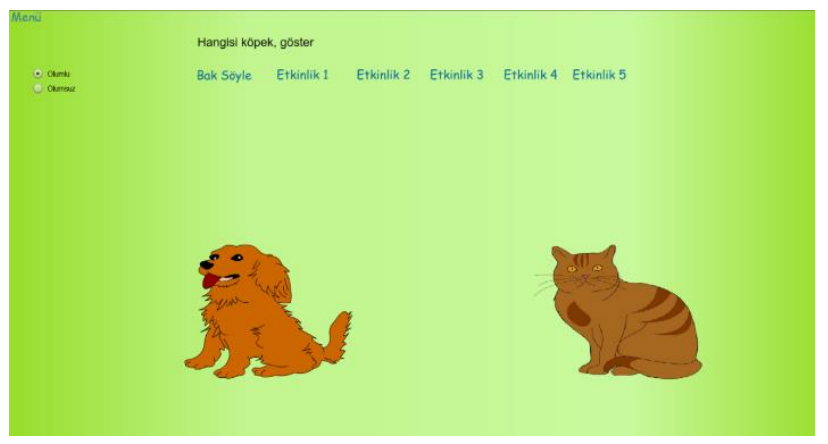

Figure 2. Which is the dog, show.

\section{Findings}

This research investigated the impact of IWB firstly on (1) students' participation in the classroom, and (2) teachers' teaching practices.

\section{Impact on Students Participation}

With regard to the impact on students, they did not experience any problems using the IWB. They were able to touch most areas of the IWB, except for the very top, and they didn't experience any difficulties in doing so.

The teachers stated that students need to have skills in the use of IWBs, and intellectually disabled students have limited skills compared to their peers. For example, it has been observed that students with autism are very distracted and they respond to the command 'look at me'only after it is repeated many times. Teachers have stated that these students should have been given some simple instructions in advance.

Students need to have some certain skills before working with the IWB. Students 1 showed a little ability. He was able to acquire the skill after carrying out practice exercises on the IWB (Teacher 1).

Teachers also reported that students who did not have any pre-skills were able to acquire the basic presentation skills needed to use the IWB.

\section{Visual quality, durability and multimedia}

Teachers have indicated that largerand better quality visuals make teaching more effective compared to traditional teaching materials for these students. They assert also that assistive multimedia tools such as audio and video files, as well as animations, are advantages brought by technology to students with disabilities. For example, teaching how to identify an animal by its sound, picture and video would increase the motivation of students and increase the retention of the taught content, a result which cannot be achieved by traditional learning materials.

The Ministry of Educationdoes not provide visual and tactile materials so we create them ourselves. For example, we develop cards to teach them the difference between short and tall. However, the quality of education is quite poor when materials of this kind are used. With a IWB in the classroom, we would add colors, zoom in and zoom out on the picture and we would be able to have more effective teaching materials. (Teacher 1)

They have said that they use materials from thick cardboard because traditional materials are being damaged by students. Therefore, IWB seem advantageous due to the absence of these problems.

We create materials from thick cardboard for students who ripup other materials (Teacher 1). 


\section{USING INTERACTIVE WHITEBOARDS AS AN ASSISTIVE TECHNOLOGY FOR STUDENTS WITH INTELLECTUAL DISABILITY}

The fact that IWBs are big is an advantage for students in terms of visual quality. The traditional materials used in the classroom are usually the size of a card that can be held in one hand. However, students can see these materials in much larger sizes on the IWB. It has been said that this makes it much easier for students to apprehendan object.

\section{It drew the attention of Student 4 visually. It positively affected Student 4 and Student 3.} (Teacher 1)

\section{Physical touchability}

IWB have some visual advantages as well as some disadvantages. For example, a negative point that teachers emphasized is that students cannot grasp and touch the material that is being taught. They stated that in traditional teaching the object being taught can be presented as a physical teaching material, in three dimensions, and students can touch and examine it in whatever way they like. Therefore, they suggested that, before IWB are used in the classroom, traditional teaching methods should be used first.

The student was not able to touch the material being taught. When we used cards and Lego, students were able to touch and examine the materials being taught. We use pictures after teaching the objects in this way (Teacher 2).

On the other hand, when we asked teachers whether they have these materials available in school, they said they do not have them.

According to the interviews, giving students the opportunity to touch the IWB while they are learning a new object or concept is considered advantageous. One of the special education experts suggested that students use their motor skills when they touch the IWB and interacting with objects is more effective compared to just looking at the objects displayed on the IWB. It should be noted also that experts interviewed while developing content prior to the study agreed with this suggestion.

Cards are more cognitive; with these technologies, more motor skills are required to be used (Teacher 1).

\section{New behaviors}

Teachers stated that students gained new behaviors after using the IWB in the classroom. These behaviors are the ones related to how students should stand in front of the IWB. Students used to exhibit different behaviors in front of the IWB; however, they have learnt how to behave in front of the IWB and to follow the directives of the teachers.

Students gained new behaviors such as waiting with their hands at their sides while they are waiting in front of the IWB. (Teacher 1)

According to teachers, one student who used to talk a lot during classeshas become quieter in courses conducted with the IWB. This is confirmed in the video recording taken during the classes, where it can be seen that the same student seems to be unusually quiet, as reported by the teachers.

Student 2 used to be a very chatty and noisy child. However, he made little noise when

we performed the class with anIWB. (Teacher 1)

According to the observations, a student who used to be very active and a disturbing influence during the class becamemuch calmer and gave his attention to the IWB in the lessons.

\section{Group training}

Difficulties experienced in group training are considered to be one of the disadvantages of IWBs. Teachers lost their control over the classroom when they dealt with one student on the IWB since they couldn't maintain their eye contact with the others. These students do not follow directives such as 'be quiet, stop, don't do it' as their peers with no disabilities do. As a result, teachers experienced some problems in maintaining control of the class. 
However, teachers stated that group training alsohas some advantages and they achieved some gains in these studies that they cannot achieve by working with students one to one. For example, other students often learn something by latent learning when the teacher is working with another student.

Students learn by latent learning when I teach something to another student. (Teacher1).

\section{Differences of students in their obsessive behaviors}

Another finding of the study is that students with different characteristics react differently to the content presented on the IWB. Teachers indicated that students with autism, Down's Syndrome and intellectual disorders react differently to the sounds and effects in the interactive teaching sessions.

\section{In the sessions, different things such as a red light drew the attention of students with autism. In fact, different things may attract the attention of students in regular teaching sessions as well. (Teacher 1)}

These behaviors mentioned by teachers are captured in the video recordings. A student with autism was interested in the power cord of the IWB instead of answering the question asked by the teacher. In another recording, the same student touched the red power light under the IWB and focused on that.

It canbe seen that the student with Down's Syndrome exhibited a different kind of obsessive behavior. The lion is located on the left when the teacher describes the image in the first activity. It is located on the right side in the second activity. In the first activity, the student was able to touch the lion on the left correctly and some effects immediately appeared. In the second activity, the lion was placed on the right side and the student was asked to touch the lion. However, he expected the effects to appear after touching the left side, so he touched the dog placed on the left side of the IWB rather than touching the lion and waited for the effects to show (Figure 2).

\section{People with autistic disorders can be obsessed with certain things. For example, student 3 (with Down's Syndrome) wants to touch the IWB all the time and waits for stars to come out and hear their sounds. It is expected to see such behavior in children with autism, but it does not happen all the time. It may be very effective in one, while it may not be very effective in another one (Teacher 2).}

As can be seen in Figure 2, the student is asked to indicate the lion placed on the right. However, he is indicating and touching the left side of the IWB and waits for the effects to be displayed, because the lion was placed on the left side in the previous practices and the student expects to see the effects and hear the sound when he/she touches the left side of the IWB.

Also, teachers stated that not all the students with the same kind of disability exhibit the same behaviors, due to individual differences. Students may react differently even if they have the same disorder. Two students with autism or intellectual disorder may react differently even though they have the same diagnosis.

\section{We cannot claim that all autistics exhibit problematic behaviors with this IWB. It may have positive impacts on one, while another exhibits obsessed behaviors and the next does not exhibit these behaviors. (Teacher 2)}

However, when we watched the video recordings once again, we saw that they exhibit obsessed behaviors occasionally but not all the time. Students are expected over time to adapt better on and focus better on the subjects being taught.

\section{Designing the classroom}

Teachers stated that classrooms should be designed in accordance with the characteristics of the students, and that objects distracting their attention should be removed from the environment. Any object can distract students, such as the power cable and power light of the IWBas described before. Removing distractingobjects and taking students into 


\section{USING INTERACTIVE WHITEBOARDS AS AN ASSISTIVE TECHNOLOGY FOR STUDENTS WITH INTELLECTUAL DISABILITY}

consideration in designing the classroom can reduce the problems encountered during the learning and teaching process.

Classrooms should be well designed by knowing the students very well. For example, a student can be obsessed about the trash and he/she can be distracted. (Teacher 1)

For example, a student with autism can become obsessed with a teacher's watch duringclass. In this situation the teacher responded by putting the watch into a cupboard out of view and continued with the class. However, one student opened the cupboard and took the watch while one of his friends was working at the board. From these examples, it has seen that some problems are not related to the actual use of theIWB and classroom conditions should be kept as simple as possible, even though traditional teaching methods are being used.

Teachers stated that these problems are not encountered only in relation to the IWB.They are experienced in traditional teaching sessions also, as these students are different to the normal student profile.

These are not normal kids, so these problems will be eventually encountered. We experience various problems in traditional teaching activities too. For example, they rip the material out and leave as if nothing has happened. (Teacher 2)

Another issue mentioned by teachers is that students improve their technological skills by using the IWB. They say that students became more interested in other technologies after using the IWB and they tried to use other technological devices too.

For example, Student 1, who was one of our very problematic students, was not able to establish eye contact. He showed more interest in electronic devices after using the IWB. He unlocked the phone. It may be latent learning (A teacher, who was not included in the sample, but participated during the interview).

\section{Impact on Teaching Practice}

As a result of the study, it was observed that teachers showed an intense interest in the IWB. The other teachers at school also wanted to use this technology in their classrooms and indicated that it would be very beneficial for the process of teaching and learning.

According to pre-interviews, teachers think that the use of IWB will give very positive results. However, they stated that they did not get all the benefits they were expecting to have prior to the study, due to some problems and limitations encountered. Theysaid that they experienced some problems at the beginning due to the fact they were using a new technology, they did not have sufficient information on how to use the boards effectively and students were exhibiting problematic behaviors.

\footnotetext{
At first, it wasthought that it would be very effective. Butas we could not keep others under control while dealing with one studentatthe board, problematic behaviors were encountered (Teacher 1).
}

But these problems were overcome in the following weeks. They get used to IWB for a while. Some of the teachers' opinions on this issue are as follows:

\section{It can be used for special education, and its disadvantages can be reduced over a certain time period. (Teacher 1)}

We get used to this technology after using it for a while and it would be great for students. (Teacher 1)

\section{Class control}

In the first days of the project, teachers presented the concept to be taught on the IWB at the beginning of the course. Then, they conducted individual activities with each student about the concept of the day. They hadsometroublekeepingthe other students under control while doing activities with individualstudents. They hadtointerrupt these activities to keep the other students under control. However, as there are two teachers in the classroom for 
special education, such problems werenot encountered. Also, the problematic behavior of the students was reduced in the following weeks and they waited more quietly.

There was a difference between the first and last lesson. Students were used to walking around, but they changed this behavior in the viewing sessions. Students learned how to react. Their learning process has become much easier. (Teacher 1)

In this respect, although teachers initially stated that it would be difficult to maintain good classroom management, they were able to overcome this issue after a while.

Teachers can overcome negative behavior over time through their own skills. As a result of the project, students' performance levels were improved. (Teacher 1)

\section{Workload for teachers}

Although teachers were expecting IWBs to be very effective, they experienced some difficulties while using the boards.

There are some advantages for sure, but I do not agree that the teachers' job will be much easier. (Teacher 1)

In fact, it doesn't make our jobs easier. It makes it more difficult. It may be easier when we get used to it. (Teacher 2)

From the interviews held with teachers, it was evident that these negativities could be eliminated over time. AsIWBs are new technologies, teachers adapt to them over time and they can be used more widely and effectively.

I have been teaching using traditional teaching methods for 4 years. Students get used to this technology in this time. This is new to them. It would be great for them if we were able to use it for 2-3 years. (Teacher 1)

Even though teachers experienced some problems while using IWBs in the classrooms in their first classes, they stated that this technology could be used for students who need special education. Teachers were able to carry out teaching practice in only one subject within a period of only two months. According to teachers, the use of IWBs can be broadened by creating content in other subjects. In addition, the disadvantages of the boards can be minimized over time.

We drew the attention of all the children to the target behavior. It was tough at first because of their problematic behaviors. However, in the maintenance sessions, we have seen that the interactive white board could be used effectively and usefully for students. (Teacher 1)

I think they can be used in special education. Their disadvantages can be minimized after a while. (Teacher 1)

\section{Other activities with iwb}

Teachers also indicated that they have used the IWB in a variety of activities out of the scope of the project. The board has provided a different standpoint for students and teachers. For example, by connecting to the internet, they have watched cartoons on the board as a reward for students.

We used it to write, read, and watch videos as well as to write letters. (Teacher 2)

We used the board for animations and watched cartoons for socialization of the kids.

They see cartoon characters on the board. We allowed them to watch cartoons as a reward. (Teacher 1)

Both teachers and administrators were interested in the IWB. Teachers wanted to use the IWB in their classrooms.

Other teachers in school want to spread this technology to all classrooms so that they can benefit from our experience. We will even give a seminar on this subject. They are positive about this. (Teacher 1) 


\section{USING INTERACTIVE WHITEBOARDS AS AN ASSISTIVE TECHNOLOGY FOR STUDENTS WITH INTELLECTUAL DISABILITY}

\section{Discussion}

\section{Impact on Students Participation}

Courses held with IWBs allowed students to actively participate and this is considered to be an advantage by classroom teachers. In the literature, it is indicated that students with intellectual disabilities learn better when they actively participate in a course. They receive feedback as they participate in the classroom and this feedback helps them to learn more (Eripek, 1998). The larger size of the IWB is considered as an advantage since students can see the visuals more comfortably in larger dimensions. Teachers have indicated that the picture cards they use are usually small and larger visuals displayed on anIWB make the learning process more effective. According to one study, it is suggested that intellectually disabled people can perform activities more easily with larger objects and screens (Lopresti et al., 2008).

Also, the larger size of the IWB improved the effectiveness of the activities in the course and allowed the teachers to conduct teamwork since all students could easily see the board. Although it has been stated that teachers have difficulties in keeping all the children under control while using the IWBs, they also considered them to be an advantage, especially for teamwork. Teachers were able to develop effective teamwork throughthe IWBs and this led to benefits which are difficult to obtain inindividual one-to-one work with students. From the literature, it is evident that the common effect on students is to lead them to actively participate in the course (Eripek, 1998). Tuncer and Altunay (2012) observed that when a teacher asks a common question to all students, they all focus on the course. However, they have also suggested that the same question should be asked to anylower performing students to make sure all of them learn the concept.

Students did not have any difficulties using the board. In the literature, it is known that individuals with intellectual disabilities have trouble using non-touchscreen computers and they rarely have the required hand-eye coordination to use these devices(Gönener, Güler, Altay, \& Aç1l, 2010). In a study byUzun, Kaya, Kurşun, and Cagiltay (2011), it is reported that using a touchscreen is easier than using a mouse for students with lower motor skills. This information is consistent with the observations made in this study and it has been suggested that the use of touchscreen devices is more adventurous for these students. Williams and Nicholas (2006) suggested that the motor skills of intellectually disabled students may be poor and they could better focus on what they are doing without using a keyboard or mouse. In the same study, researchers indicated that these students wanted to touch the screen all the time and this issue could be resolved by using a touchscreen display.

One of the teachers suggested that students using their motor skills by touching the board, and having interaction with the object rather than just looking at it, is more effective for learning. Other experts supported this suggestion. It has also been claimed in the literature that creating an interaction betweenthe student and the material to be learned gives better results than traditional teaching methods (E. Tekinarslan \& Yk1klmış, 2005). According to the teachers, using assistive multimedia tools such as audio and video files as well as animations are advantageous for these children. It is known that aids of this kind facilitate learning by including multiple senses in the process (Avc1, 2009; Dale, 1969). It is also thought that IWBs may have an important impact on the learning process of intellectually disabled students by encouraging the use of these channels. Students need to be supported by positive motivation tools to make them feel successful (Bishop, 1999).

An advantage of IWBs is that traditional materials get damaged over time, whereas multimedia materials last forever. Multimedia materials can be used again and again (Çelik, 2007; Koşar et al., 2005). In one study, a person with an intellectually disabled child was able to increase and decrease speed as he/she desired on the computer, and could repeat a process hundreds of times without the computer's patience running out and he/she was able to freely adapt these processes according to requirements(Jeffs, Morrison, Messenheimer, Rizza, \& Banister, 2003). Advantage of multimedia materials is that they can be developed to meet the needs of eachstudent, whereas it is not possible in traditional methods (Avc1, 2009). On the other hand, teachers indicated that one of the disadvantages of multimedia 
materials is that students are not able to hold the objects with their hands and examine them as they can do with traditional learning materials. This is consistent with Dale's Cone of Experience. According to Dale's Cone of Experience, holding an object rather than just looking at it is more effective for children in promoting better learning. However, teachers also mentioned the important matter of material shortages in school.

One student in particular with autism was distracted by the red power light on the board and by the teacher's watch. However, the teachers stated that these behaviors disappeared after a period of time and the researchers confirmed this from their observations. It is generally accepted that students with autism in particular can become obsessed with certain objects (Kodal, 2006). Therefore, classrooms should be designed according to the characteristics of the students. As students with autism are often distracted by rotating and flashing objects, the education environment should be designed with this in mind(Ozen, 2012; I. C. Tekinarslan, 2012).Williams and Nicholas (2006) also suggested that education environments should be adapted to the characteristics of students. During practices. the attention of students was attracted by different things on the IWB.However, teachers stated that the same problems can be encountered during courses given using traditional methods. It has been concluded that if obiects with the potential to distract students are removed from the environment, then the education of the students is likely to be more successful. In line with this conclusion, according to studies in the literature, designing classroom environments bv taking these individuals into consideration is extremely effective in increasing their success (Güven, 2008).

Teachers have stated that students acquire new behaviors in classes where the IWB is used. One student learned the instruction 'wait with your hands by your sides' while standing. Another student was not used to responding to the commands 'look or show', but teachers stated that this student learned to respond to these commands when given by the instructor. Another student was well-known for talking too much in regular classes. However, but he/she became quieter in the courses conducted with the IWB.

Another issue highlighted by teachers is that the use of IWBs can improve the technological skills of the students. Although the main purpose of using these boards is to provide better learning for these students, their technological skills have been improved as well. From studies in the literature, it is evident that allowing students to acquire technological skills in addition to learning new things is a significant factor (Boyle \& Scanlon, 2009). In addition, again from studies in the literature, it appears that using computers improves students' problem-solving capabilities (Twyman \& Tindal, 2006).

As the IWB is a new technology for both students and teachers, it may take some time to get used to it. The initial problems with their use were reduced over time. The larger size of the board and using assistive multimedia materials such as audio-video files are great advantages for these children. Some of the problems encountered in classes conducted with IWBs can also be encountered in traditional teaching methods. Therefore, it is thought that these problems can be eliminated by taking students' individual characteristics into account and designing classrooms in accordance with the needs of these students. In this way, it is believed that these new technologies can be used more effectively in the classroom.

\section{Impact on Teaching Practice}

Since the IWB used within the scope of the study is a new technology for the classroom and both teachers and students were not used to having such a technological device, teachers have experienced some problems in the beginning. These problems were mainlv due to the fact that the teacher was able to work on the board with only one student at a time and it was necessary to turn his/her back to other students. In the traditional teaching method, teachers establish eve contact with all the students and in this wav manage to keep the class under control(Arpacik, Kursun, \& Göktas, 2013). Difficulties were experienced as these students do not follow straight-forwarddirectives such as 'be quiet, stop, don't do it' as their peers without disabilities do. and thev started to exhibit problematic behaviors. However. the teachers stated that these behaviors reduced over time. Previous studies in the literature 


\section{USING INTERACTIVE WHITEBOARDS AS AN ASSISTIVE TECHNOLOGY FOR STUDENTS WITH INTELLECTUAL DISABILITY}

indicate that active participation of students reduces the probability of these problematic behaviors occurring(Eripek, 1998). In this study, it was found that the use of the IWB in the classroom encouraged students to participate in the course.

Since IWBs are a new technology for the teachers, they have stated that they found difficulty in using the boards at first. Adapting to a new technology always takes time(Rogers Everett. 1995). The imbortant thing is to shorten the adaptation period as much as possible. Although teachers had difficulties at first, they became accustomed to the technology in the following weeks, and also stated that the problems encountered at the beginning were greatlv reduced. In addition. thev felt that their iob would become much easier when they obtained full access to the necessary content they require, and the use of IWBs becomesmore widespread.

Fore. Martin. and N. Bender (2002)indicated that burnout levels of special education teachers are higherdue to the overwhelming responsibilities placed on the teachers. It is thought that the use of IWBs will positively affect burnout levels of the teachers by easing their iobs to some extent. Both teachers and administrators were interested in the IWB used at school. Other teachers also wanted to use the board in their classrooms. From previous studies in the literature, burnout levels of special education teachers were found to be higher compared to other teachers (Sahin \& Sahin. 2012). Schools for special education are also included in the FATIH project. Therefore, it is believed that using IWBs in classrooms will have a positive impact on teachersin special education schools.

\section{Conclusion}

The studv has some limitations. The first limitation is that there was onlv one special education school for students with intellectual disabilitv in the citv. located east nart of Turkev. when the studv was imnlemented. The samnle size was limited at the school and the samples were selected from different classrooms. The students who formed the sample had different disorders. The teachers in these classrooms had never used such technologv hefore so their attitudes and annroaches towards the technologv were not well established. Teacher 1 was more experienced than Teacher 2 . therefore Teacher 1 answered more in the interviews. Finally, the study was conducted within a limited period of time about six weeks.

In conclusion. the following items summarizes the imnact of integrating IWB in formal learning settings of students with intellectual disabilitv. With regard to students:

- Although theIWB is a new technologv in the classroom. students were comfortable in using it. However, some pre-skill is requiredfor the intellectually disabled to use this board. The larger size of the IWB and its capability of supporting multimedia materials is considered to be a definite advantage.

- In the traditional learning method, students are able to touch the material-object being taught. However, in this new technology they cannot hold the object with their hands, which can be a disadvantage.

- Students are able to touch the board and interact with the materials. This is considered to be a significant advantage.

- Students gain new positivebehaviors during process. training.

- It was concluded that the IWB has both advantages and disadvantages for group

- It was observed that technologv can create different impacts on different students.

- It was recommended that the education environment should be designed by taking students' needs into consideration.

With regard to teachers;

- It was found that teachers showed a positive interest in the IWBs.

- Teachers had some trouble with class management at the beginning, but they wereabletoovercome these problems over time.

- Teachers indicated that theIWB has both advantages and disadvantages, butthatthedisadvantages werereduced after using the board for a period of time. 


\section{References}

Allsopp, D. H., Colucci, K., Doone, E., Perez, L., Bryant Jr, E., \& Holhfeld, T. N. (2012). Interactive whiteboard technology for students with disabilities: A year long exploratory study. Journal of Special Education Technology, 27(4), 1-15.

Arpacık, Ö., Kurşun, E., \& Göktaş, Y. (2013). Experience of development materials suitable with interactive boards for students with learning disability: A case study. Paper presented at the 1st International Instructional Technologies \& Teacher Education Symposium, Trabzon.

Avcı, U. (2009). Öğretim ortamları ve materyal tasarımı [Teaching environments and material design]. In M. Sarttaş (Ed.), Öğretim teknolojileri ve materyal tasarımı[Instructional technologies and designing materials] (Vol. 2 Baski). Ankara: Pegem Akademi.

Bishop, M. E. (1999). Teaching students who have mental retardation. Catechist, 32, 1.

Boyle, J., \& Scanlon, D. (2009). Methods and strategies for teaching students with mild disabilities: A case-based approach. In. Retrieved from http://books.google.com.tr/books?id=n3iDiH9vG5MC\&pg=PA2\&dq=Characteristics + of + and + S trategies+for+Teaching+Students+with+Mild+Disabilities.\&hl=tr\&sa=X\&ei=Y6EQUfbDKiL4gT4jo Go Cw\&red ir_esc=y\#v=onepage\&q\&f=false

Braddock, D., Rizzolo, M. C., Thompson, M., \& Bell, R. (2004). Emerging technologies and cognitive dis ability. Journal of Special Education Technology, 19 (4), 14.

Çelik, L. (2007). Öğretim teknolojileri ve materyal tasarımı. [Instructional technologies and designing materials] Ankara: Pegem A Yayıncilik.

Dale, E. (1969). Audiovisual methods in teaching. New York: Dryden Press.

Davies, D. K., Stock, S. E., \& Wehmeyer, M. L. (2004). Computer-mediated, self-directed computer training and skill assessment for individuals with mental retardation. Journal of Developmental and Physical Disabilities, 16(1), 11.

Eripek, S. (1998). Zihinsel engelliler [Intellectual disability]. In S. Eripek (Ed.), Özel eğitim [Speacial education] (pp. 39-54). Eskişehir: Anadolu Üniversitesi.

Fore, C., Martin, C., \& Bender, W. N. (2002). Teacher burnout in special education: The causes and the recommended solutions. The High School Journal, 86(1), 36-44.

Gönener, H. D., Güler, Y., Altay, B., \& Açıl, A. (2010). Zihinsel engelli çocuklarin evde bakimi ve hemşirelik yaklaşım. [Caring of a mental-impaired child at home and nursing approach.]Gaziantep Tip Dergisi, $16(2), 9$.

Güven, M. (2008). Öğretim materyali ve tasarim süreci [Instructional material and design process]. In K. Selvi (Ed.), Ögretim teknolojileri ve materyal tasarımı [Instructional technologies and designing materials]. Ankara.

Jeffs, T., Behrmann, M., \& Bannan-Ritland, B. (2006). Assistive technology and literacy learning: reflections of parents and children. Journal of Special Education Technology, 21, 8.

Jeffs, T., Morrison, W. F., Messenheimer, T., Rizza, M. G., \& Banister, S. (2003). A retrospective analysis of technological advancements in special education. Computers in the Schools, 20(1-2), 129-152. doi:10.1300/J025v20n01_10

Kodal, B. (2006). Eskişehir ilinde otistik çocuklarla çalışan özel eğitim öğretmenlerinin yaşadıkları sorunlar ve sorunların çözümüne ilişkin görüşleri. [The opinions of special education teachers working with children with autism in Eskişehir about their problems and the solutions of the suggestions while working with them]. (Doktora), Anadolu Üniversitesi, Eskişehir, Türkiye.

Koşar, E., Yüksel, S., Özkılıç, R., Sarıtaş, M., Şentürk, A., \& Çiğdem, H. (2005). Eğitim ortam tasarimi, araç-gereç ve materyal özellikleri [Educational environment design, materials and materials properties]. Ankara: Pegem A Yayincilik.

Lopresti, E. F., Bodine, C., \& Lewis, C. (2008). Assistive technology for cognition [Understanding the needs of persons with disabilities]. IEEE Engineering In Medicine And Biology Magazine, 11. 


\section{USING INTERACTIVE WHITEBOARDS AS AN ASSISTIVE TECHNOLOGY FOR STUDENTS WITH INTELLECTUAL DISABILITY}

Mosito, C. P., Warnick, A. M., \& Esambe, E. E. (2017). Enhancing reading abilities of learners with intellectual impairments through computer technology. African Journal of Disability, 6(1), 10. doi:10.4102/ajod.v6i0.206

Özen, A. (2012). Özel gereksinimli bireyler. In E. T. İftar (Ed.), Özel gereksinimli bireyler ve bakim hizmetleri[Special needs individual and care services]. Eskişehir: Anadolu Üniversitesi.

Roblyer, M. D., \& Edwards, J. (2000). Integrating educational technology into teaching. In: Upper Saddle River, NJ: Prentice-Hallo02E

Rogers Everett, M. (1995). Diffusion of innovations. New York, 12.

Rose, D. H., Hasselbring, T. S., Stahl, S., \& Zabala, J. (2005). Assistive technology and universal design for learning: two sides of the same coin In D. Edyburn, K. Higgins, \& R. Boone (Eds.), Handbook of special education technology research and practice (pp. 13). Whitefish Bay: WI: Knowledge by Design.

Stahl, B. C., Rogerson, S., \& Wakunuma, K. J. (2009). Future technologies: the matter of emergent ethical issues in their development. Paper presented at the 2009 Computation World: Future Computing, Service Computation, Cognitive, Adaptive, Content, Patterns, Athens.

Şahin, F., \& Şahin, D. (2012). Engelli bireylerle çalşsan özel eğitim öğretmenlerinin tükenmişlik düzeyinin belirlenmesi [Examining the burn-out level of special education teachers working with disabled individuals]. Ögretmen Ĕgitimi ve Ĕ̈itimcileri Dergisi [Journal of Teacher Education and Educators], 1(2), 20.

Tekinarslan, E., \& Yıkılmış, A. (2005). Özel eğitim kurumlarında çalışan öğretmenlerin teknoloji kullanımına yönelik görüşleri ve beklentileri [Teachers' opinions and expectations toward the use of technology in special education institutions]. Abant Izzet Baysal Üniversitesi Sosyal Bilimler Enstitüsü Dergisi [Abant İzet Baysal University Graduate School of Social Sciences Journal of Social Sciences], 2(11), 10.

Tekinarslan, İ. Ç. (2012). Zihinsel yetersizliği olan öğrenciler [Students with mental disabilities] In İ. H. Diken (Ed.), Özel ĕgitime gereksinimi olan ögrenciler ve özel ĕgitim.[Students with special needs and special education.] Ankara.

Tuncer, T., \& Altunay, B. (2012). Doğrudan öğretim modelinde kavram ögrretimi[Concept teaching in direct instrucion model]. Ankara: KÖK Yayıncilik.

Twyman, T., \& Tindal, G. (2006). Using a computer-adapted, conceptually based history text to increase comprehension and problem-solving skills of students with disabilities. Journal of Special Education Technology, 21(2), 12.

Uzun, C., Kaya, K. Y., Kurşun, E., \& Cagiltay, K. (2011). Critical points and dynamics of instructional design and development process in the creation oflearning material for teaching basic concepts to students with mental disabilities via multitouch screen. Paper presented at the 5th International Computer \& Instructional Technologies Symposium, Firat University, ELAZIĞ- TURKEY

Whitby, P. J., Leininger, M. L., \& Grillo, K. (2012). Tips for using interactive whiteboards to increas e participation of students with disabilities. Teaching Exceptional Children, 44(6), 50-57.

Wiley, B., Cameron, D., Gulati, S., \& Hogg, A. (2016). Exploring the use of tablets (iPads) with children and young adults with disabilities in Trinidad. Disability and Rehabilitation-Assistive Technology, I1(1), 32-37. doi:10.3109/17483107.2014.914251

Williams, P., \& Nicholas, D. (2006). Testing the usability of information technology applications with learners with special educational needs (SEN). Journal of Research in Special Educational Needs, 6(1), 11.

World Health Organization., \& World Bank. (2011). World report on disability. Geneva, Switzerland: World Health Organization.

Ylldı, S. (2010). Bilgi ve iletişim teknolojileri yoluyla özürlüler için geleceğe bir kap1 açmak. Uluslararast Sosyal Araștırmalar Dergisi, 3(11), 9. 